\title{
Review on Coffee Production and Marketing in Ethiopia
}

\author{
Jima Degaga \\ Department of Agricultural Economics, Ambo University, P. O. Box 19, Ambo, Ethiopia
}

\begin{abstract}
Coffee, Ethiopia's largest export crop is the backbone of the Ethiopian economy. However, Ethiopia has not yet fully exploited its position as the producer of some of the best coffees in the world. Hence, a little information has been gathered on different aspects of the coffee with the objectives of reviewing coffee production and marketing in Ethiopia, and marketing actors and margin distribution of coffee in Ethiopia. Data from FAOSTAT, CSA and different published materials on coffee were used. According to the review, lack of competitiveness, lack of infrastructure, in adequate access to services, low value addition, in adequate technology transfer and research, competition of khat and rainfall variability are among major constraints of coffee production in Ethiopia. Price volatility, Poor accesses to market, little market promotion and incentive mechanism, and low price were reported to be the major problem of coffee marketing in Ethiopia. Licensing of more traders and inspecting their activities, enhancing infrastructural and institutional facilities and improving of coffee production technologies through development, and extension of improved coffee varieties and other related agronomic practices were among the major recommendations forwarded from the review.
\end{abstract}

Keywords: Coffee, Ethiopia, Production, Marketing

DOI: $10.7176 / \mathrm{JMCR} / 67-02$

Publication date: April $30^{\text {th }} 2020$

\section{Introduction}

\subsection{Background of the Review}

Agricultural sector has been the priority of Ethiopia since the early 1990s, when the Agricultural DevelopmentLed Industrialization (ADLI) and related policy frameworks were adopted (FAO, 2014). More than $70 \%$ of Ethiopia's population is still employed in the agricultural sector. The share of agriculture in the GDP has declined over five years from $44.7 \%$ in $2010 / 11$ to $37.2 \%$ in $2015 / 16$. Despite its declining contribution to GDP over five years, agriculture remains the leading sector in terms of contribution to the country's overall economy. It is the major source of food for domestic consumption, of raw materials for the domestic manufacturing industries and of primary commodities for export (Edward et al., 2017).

The Government of Ethiopia has recently embarked upon exploring new knowledge from outside the country in order to accelerate its market-oriented agricultural development. These areas of new knowledge include technologies, biotechnological tools and products, institutional innovations and arrangements for extension, output marketing, input supply and rural finance (ILRI, 2005). It has developed long term and strategic framework to improve the quality of farm product and traded commodities, reduce marketing costs and increase competition in the marketing sector (Tesfaye, 2016).

But, till today agricultural commodity market is not stable. This is because, there is no well integrated commodity marketing policy that addresses all the processes that involve transport, grading, storage and information facilities for the producer as well as for consumer, and well-equipped institutional establishment which can provide all marketing services to all market actors (Tesfaye, 2016). Limited credit supply, price instability, and Market and price information not accessible to producers and local traders are also among major constraints of agricultural marketing in Ethiopia (Mohammed, 2004). The poor performance of marketing system is believed to be on the main factors responsible for the declining productivity of labor in Ethiopian agriculture (Wolday, 1994).

Coffee, Ethiopia's largest export crop is the backbone of the Ethiopian economy. Ethiopia has not yet fully exploited its position as the producer of some of the best coffees in the world. Coffee sector is highly dependent on international prices and affected by the structure and workings of the world coffee market. Ethiopia is one of the countries mostly affected by the crisis in world coffee prices (Nicolas, 2007). Notwithstanding the severe price shocks that have been shacking its value chain, coffee remains a fundamental component of the Ethiopian economy and export. Nevertheless, the prolonged price decline has substantially weakened its production basis and prospects so that appropriate financial services are urgently needed to sustain rural communities (Bastin and Matteucci, 2007).

Understanding of coffee production and marketing constraints, marketing actors and margin distribution is important in designing and implementing appropriate technological, policy and institutional strategies to improve coffee production and productivity in Ethiopia. Development of well-performing marketing system which satisfies consumer demands with the minimum margin between producers and consumer prices is important. Therefore, it is important to review coffee production and marketing constraints, and market share among the 
actors in the marketing exchange of coffee.

\subsection{Objectives of the Review}

$\checkmark$ To review marketing and production constraints, and opportunities of coffee production in Ethiopia

$\checkmark$ To review marketing margin distribution of coffee in Ethiopia

\subsection{Significance of the Review}

The review provides information on coffee production systems, production and marketing constraints, marketing actors and their margin distribution in Ethiopia. The information is expected to have valuable input that helps market participants to understand marketing and production constraints, and performance of coffee marketing in the country. The information generated in this review can help a number of organizations including: national and international research institutions, development organizations, traders, producers, policy makers, extension service providers, government and non-governmental organizations.

\section{Discussion}

\subsection{Definition of Terms}

Marketing: Marketing is a social and managerial process by which individuals and organizations obtain what they need and want through creating and exchanging value with others. In a narrower business context, marketing involves building profitable, value-laden exchange relationships with customers. Hence, marketing is the process by which companies create value for customers and build strong customer relationships in order to capture value from customers in return (Armstrong and Kotler, 2015). Marketing as a process by which individuals and groups obtain what they need and want by creating and exchanging products and value with others. It is the process of building profitable customer relationships by creating value for customers and capturing value in return (Kotler et al., 1999). Crawford (1997) defined marketing as the integrative force that matches production to customer needs and satisfaction. Marketing is not an activity to which an organization turns its attention at the end of the production phase of operations. Rather marketing needs to be directing production in accordance with clear signals from the marketplace as what is needed by customers.

Intermediaries or middle channel members: According to Palmatier et al. (2015) the term intermediary refers to any channel member other than the manufacturer or the end user. We differentiate three general types: wholesale, retail and specialized. Wholesalers include merchant wholesalers or distributors, manufacturers' representative, agents and brokers. A wholesaler sells to other channel intermediaries such as retailers or to business end users, but not to individual consumer end users. Unlike purely wholesale intermediaries, retailers sell directly to individual consumer end users. Specialized intermediaries enter the channel to perform specific functions. They are not heavily involved in the core business represented by the products being sold. For example, insurance and financing companies involved in financing, information technology firm may participate in ordering or payment functions and marketing research firms generate marketing intelligence that can support the performance of many functions.

Market performance: Performance is, as always, defined variously and much debated (Scarborough and Kydd, 1992). According to Olukosi (2017) it is the strategic end result of market adjustments engaged in by buyers and sellers. In other words, market performance is the appraisal of the extent to which the interactions of buyers and sellers in a market stimulate results that are consistent with social purposes.

Marketing Margin: It is the difference between the price received by farmers and that paid by consumers. Both producers and consumers have expressed concerns about the size of margins and have asked why marketing margins change. Moreover, if a marketing margin increases, what is the incidence of the change on farm and retail prices should be considered (Tomek and Kaiser, 2014). The marketing margin, or the farm to retail price spread, is the difference between the farm value and retail price. It represents payments for all assembling, processing, transporting, and retailing charges added to farm products (Gardner and Rausser, 2001).

\subsection{Coffee Production, Production Constraints and Opportunities in Ethiopia 2.2.1. Coffee production and production systems}

The main coffee producing areas in Ethiopia are west and south west, southern, eastern, and central regions (Melkamu, 2015). On the basis of management level, vegetation, structural complexity, and agronomic practices, coffee production systems in Ethiopia can be categorized into four; namely: forest coffee (FC), semi-managed forest coffee (SFC), garden coffee (GC) and plantation (Tadesse, 2015; Tesfu, 2012).

Forest Coffee: The forest coffee system uses wild stands of coffee, which exists naturally within the forest, and the farmer undertakes minimal management and intervention (Moat et al., 2017). The local communities living in and around the forest simply pick the wild coffee berries from naturally growing coffee plants and there is no management to improve coffee productivity. The floristic composition, diversity and structure is close to the natural situation, with little human intervention. The only management practice in the forest system is access 
clearing to allow movement in the forest during harvesting time (Tadesse, 2015). According to Labouisse et al. (2008) it includes simple coffee gathering and forest production where coffee trees are simply protected and tended for convenient picking. This system is found in southeastern and southwestern parts of the country (mainly in areas like Bale, Bench-Maji, Illubabor, Kafa, Jimma, Shaka, and West Wollega) (Boansi and Crentsil, 2013). These areas are the centers of origin of Coffea Arabica. This system accounts for about $10 \%$ of the total coffee production of the country (Melkamu, 2015).

Semi-Forest Coffee: Semi-forest coffee is more intensive, with increased farming interventions (e.g. thinning of trees, understory clearance and weed cutting, and planting of coffee seedlings) (Moat et al., 2017). Farmers acquires forest land for coffee farms, and then thin and select the forest trees to ensure both adequate sunlight and proper shade for the coffee trees (Melkamu, 2015). It is a type of coffee production system where instantly the forest coffee system is converted to semi-managed forest coffee system through reduction of plant composition, diversity and density. This is the dominant production system in southwester Ethiopia (mainly Bench-Maji, Illubabor, Jimma, Kafa, Shaka, and Wollega) and in the Bale Mountains of southeastern Ethiopia (Tadesse, 2015). This system accounts for about 35\% of the total coffee production of the country (Tesfu, 2012). Garden Coffee: is a further step in the cultivation process. Seedlings are taken from forest coffee plantations and transplanted closer to farmers' dwellings. In this system, coffee is grown in smallholdings under a few shade trees usually combined with other crops and fruit trees (Tesfu, 2012). It accounts for approximately 50\% of national production and is located near residences of growers. It is planted at low densities and is mostly fertilized with organic materials (Boansi and Crentsil, 2013). Geographically, this coffee production system is mainly found in the southern and eastern and some in southwestern parts of the country; and specifically in Gedeo, Guji, Hararghe, Jimma, Sidama, Wollega and some other places (Tadesse, 2015).

Plantation Coffee: Plantation coffee is grown on plantations owned by the state and on some well managed smallholders coffee farms. In this system, recommended agronomic practices like improved seedlings, spacing, proper mulching, manuring, weeding, shade regulation and pruning are practiced (Melkamu, 2015). This sector includes a few large private and state farms mainly located in the south-west, as well as many smallholder plantations spread all over the coffee growing areas. It accounts for about $10 \%$ of national production (Labouisse et al., 2008).

\section{Coffee production in Ethiopia}

Coffee is grown by over 4 million small holder farmers. Farmers engaged in growing and producing stimulant crops such as coffee are greater in number than those growing fruits (CSA, 2018). It employs 15 million people, or roughly 15 percent of the country's population at different points along the value chain. Nearly 95 percent is cultivated on small plots, generally less than half a hectare. Ethiopia is the world's sixth largest coffee producer, accounting for 4 percent of production. It is also the largest producer in Africa, accounting for about 40 percent of continental production (Francom, 2018).

Number of coffee producers has increased from 2012/13 to 2016/17 and then declined. Regarding total area of land allocated for the production of coffee, it has increased over the considered years though at different rates. Table (1) also indicated that there was a fluctuation in yield of coffee over the last six years in the country.

Table 1: Estimated of number of holders, area and yield of coffee over six years

\begin{tabular}{lllllcccc}
\hline Year & $\begin{array}{l}\text { Number } \\
\text { holders }\end{array}$ & of & Area (Ha) & $\begin{array}{l}\% \Delta \text { in } \\
\text { area }\end{array}$ & $\begin{array}{l}\text { Production } \\
\text { (quintals) }\end{array}$ & $\begin{array}{c}\% \Delta \text { in } \\
\text { production }\end{array}$ & $\begin{array}{c}\text { Yield } \\
(\mathrm{Qu} / \mathrm{Ha})\end{array}$ & $\begin{array}{c}\% \Delta \text { in } \\
\text { yield }\end{array}$ \\
\hline $2012 / 13$ & $4,217,961.00$ & $528,751.11$ & - & $3,739,406.42$ & - & 7.07 & - \\
$2013 / 14$ & $4,546,785.00$ & $538,466.80$ & 2.00 & $3,920,062.22$ & 5.00 & 7.28 & 3.00 \\
$2014 / 15$ & $4,723,483.00$ & $561,761.82$ & 4.00 & $4,199,801.56$ & 7.00 & 7.48 & 3.00 \\
$2015 / 16$ & $5,270,777.00$ & $653,909.76$ & 16.00 & $4,145,964.55$ & -1.00 & 6.34 & -15.00 \\
$2016 / 17$ & $6,455,194.00$ & $700,474.69$ & 7.00 & $4,690,911.24$ & 13.00 & 6.7 & 6.00 \\
$2017 / 18$ & $5,019,513.00$ & $725,961.24$ & 4.00 & $4,492,298.08$ & -4.00 & 6.19 & -8.00 \\
\hline
\end{tabular}

Source: own computation from CSA of 2012/13; 2013/14; 2014/15;2015/16; 2016/17; 2017/18.NB: " $\Delta$ " represents change

Figure 1 depicted trends of area allocated and total output obtained in the last 25 years in Ethiopia. The positive value of trend lines of output and area allocated indicated that trend of output and area have increased over the last 25 years in Ethiopia. It also showed the maximum area allocated was in 2016 which was 700475 hectares and the minimum was in 2003 (232439 hectares). Regarding output obtained, maximum was in 2017 which was 471247 tonnes and minimum was in 2003 (126188 tonnes). 


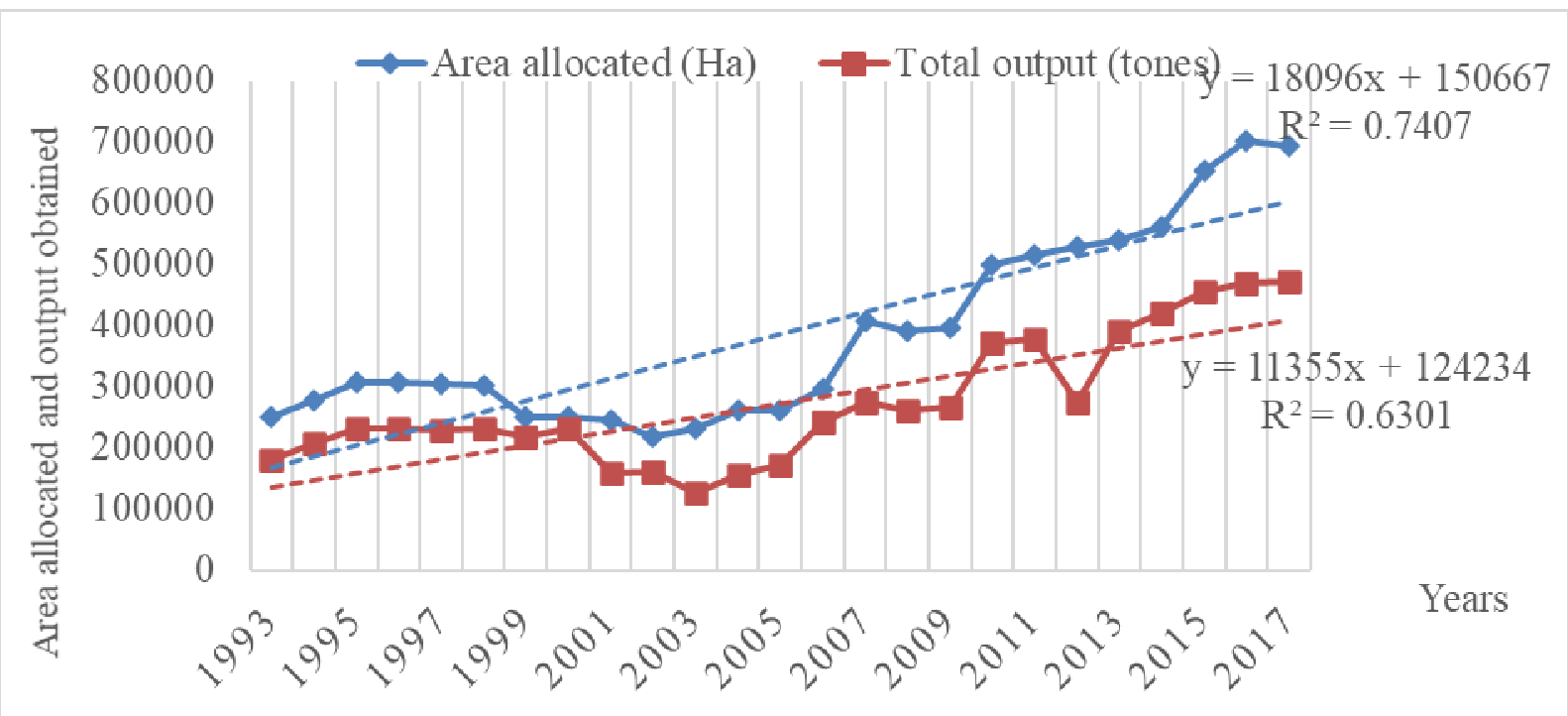

Figure 1: Trends of area allocated and output and obtained in Ethiopia for the last 25 years.

Source; Own computation from FAOSTAT data, 2019.

From figure 2, one can easily understand that the trend of coffee yield has declined. Negative value of trend line of yield implied that yield has declined over the considered 25 years. The maximum and minimum of 8.65 and 5.2 quintals per hectares was obtained in 1999 and 2012 respectively. The low value of R-square in yield trend line implies that the trend line of yield did not fit the data or there was high variation of yield over the past 25 years in Ethiopia.

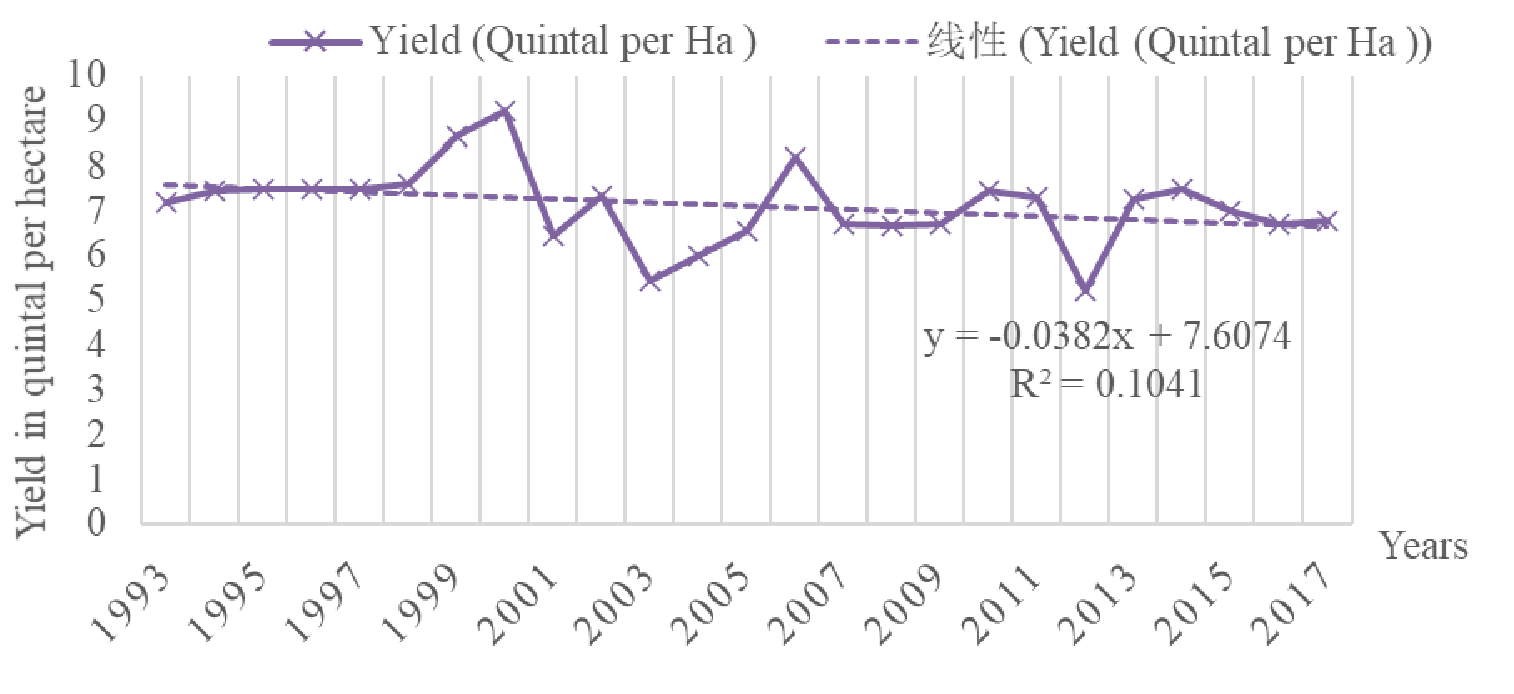

Figure 2: Trends of coffee yield over 25 years in Ethiopia

Source; Own computation from FAOSTAT, 2019.

\subsubsection{Opportunities of Coffee Production in Ethiopia}

Genetic diversity and favorable Environments, Agro-forestry based production system, already known brands in the world market, trademarked and licensed benefit to all, Modern Marketing System (ECX), Encouraging policy and coffee price are among major opportunities of coffee production in Ethiopia (Tesfu, 2012). The Ethiopian coffee sector has bright prospects. The country has suitable altitude, optimum temperature, low labor costs and fertile soil. It can sustainably produce and supply fine specialty coffee with potential of producing all coffee types of the various world coffee growing origins (Jose, 2012). Another opportunities of coffee production in Ethiopia are; high national and international demand for the product, increasing interest of private sector with high investment potential, high support by both regional and federal governments (Berhanu, 2017). The Ethiopian Coffee and Tea Development and Marketing Authority has been re-established as per the proclamation endorsed by the House of Peoples' Representatives on December 2015, with a view to boosting the country's benefit from the sector. The Authority has mandates and responsibilities; to strengthen modern extension services to attain higher level of production and increased productivity, to establish quality based 
effective and efficient marketing systems, and to support, supervise and regulating of coffee processing industries (Zelalem, 2016). Ethiopian coffee is top in both color and taste. To maintain these qualities, there is a well-established and linked structure that connects coffee farmers, processing-plant owners, governmental organization and coffee processing (Melkamu, 2015).

\subsubsection{Production constraints of coffee in Ethiopia}

Coffee production in Ethiopia is constrained by lack of competitiveness, lack of infrastructure, in adequate access to services, low value addition, and in adequate technology transfer and research (Jose, 2012). In recent days, khat, a plant chewed by humans for its stimulating effect, is competing for farm land with coffee. Some small holder coffee farmers resorted to producing khat instead of coffee as they are increasingly attracted by the high prices and greater yield they get from cultivation of khat. A significant number of farmers particularly in the eastern part of the country have switched from coffee production to khat production. Khat is drought, diseases and pest resistant plant which can be harvested three to four times a year and generates better income for farmers than other cash crops including coffee (Tolera and Gebremedin, 2015). Moat et al. (2017) reported that the other challenge of coffee production in Ethiopia is the variability of weather pattern such as rainfall variability on the onset of the wet season, extension of dry season and more extreme (drier and hotter).

According to Tadesse (2003) deforestation and change in land use are threatening coffee forest gene pools in Ethiopia. This has been aggravated with the recent coffee price crisis on the world market as a result of market liberalization. Farmers are shifting their coffee farm or forest to other monoculture crop production. Tesfu (2012) also added deforestation and land degradation, diseases, predominant traditional production, failure of using appropriate coffee technologies, inadequate services (credit, inputs, equipments), and lack of sustainability and competitiveness in the coffee sector are challenging coffee production and quality improvement in Ethiopia.

\subsubsection{Coffee export}

Ethiopia produces and exports one of the best highland coffees in the world (Samuel and Eva, 2008). Total earnings from goods export grew by 3\% in 2018 over the same quarter of last year on account of the rise in export earnings from Coffee $(19.1 \%)$, Oilseeds $(4.9 \%)$, Leather and Leather products $(27.7 \%)$, Fruits and Vegetables (16\%), Meat and Meat products (10.1\%), Flower (8.1\%), Electricity $(23.8 \%)$ and other exports (35.1\%). Earnings from coffee picked up 19.1\% in 2018 as compared to last year same quarter and reached USD 215.6 million on account of a $16.5 \%$ rise in export volume and $2.2 \%$ increase in international price. As a result, the share of coffee in total merchandise export earnings increased to $31.8 \%$ from $27.5 \%$ a year earlier (NBE, 2018). Countries such as Germany, France, Italy, Belgium, Sweden, Norway, Finland, Denmark, UK, Switzerland, USA, Japan, Saudi Arabia, Canada, Taiwan, South Korea, Australia and South Africa are traditional buyers of Ethiopian coffee (Melkamu, 2015). Agricultural exports share of total exports was declined from $86 \%$ in $2013 / 14$ to $84 \%$ in $2016 / 17$. However, coffee exports share of total exports was increased from $30 \%$ in $2013 / 14$ to $33 \%$ in $2016 / 17$.

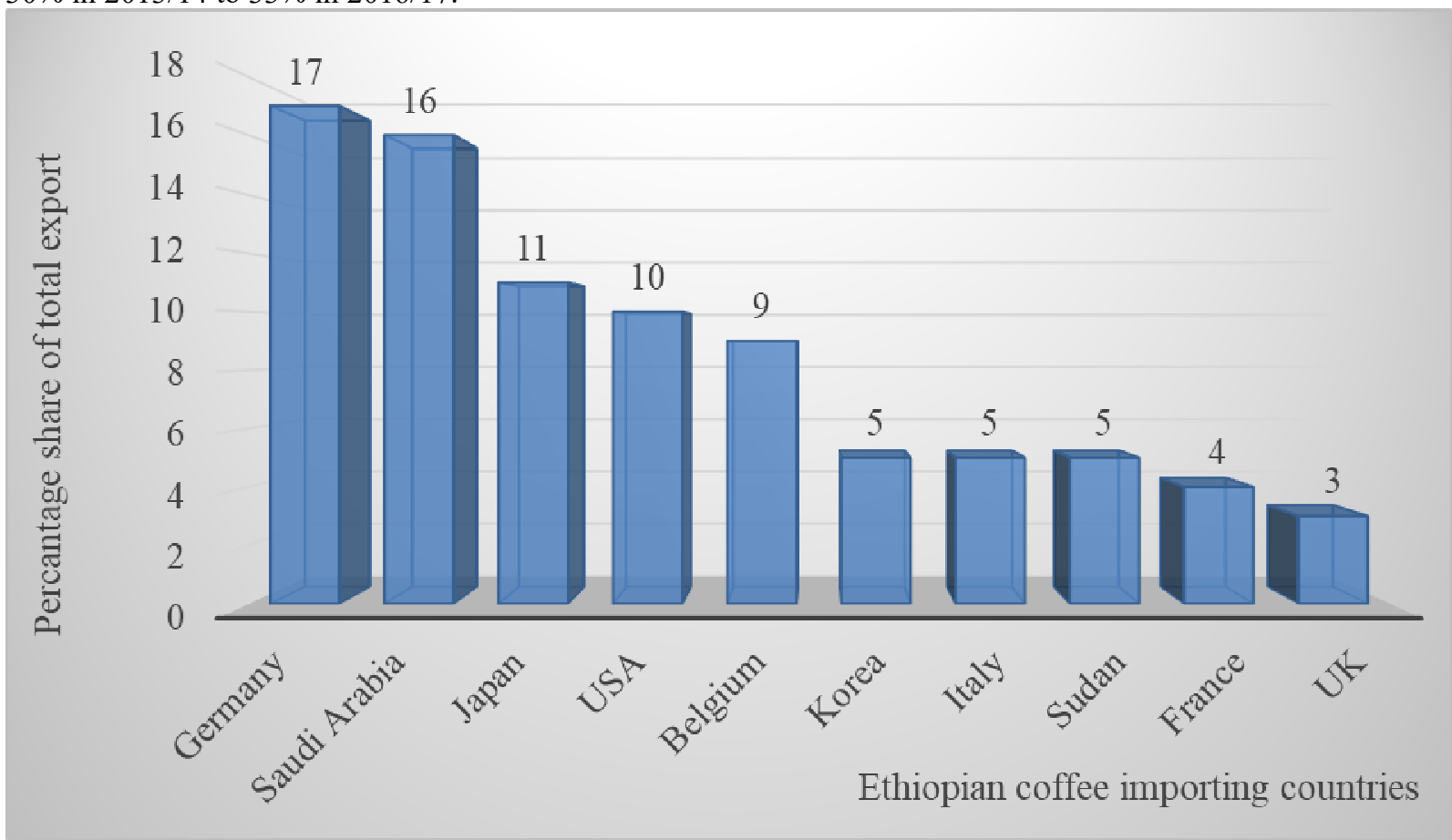

Figure 3: Top ten Ethiopian coffee importing countries by their percentage share Source: Own computation from Francom, 2018 report. 
Figure 4 indicated that trend of both export quantity and value of Ethiopian coffee has increased in the last 25 years. But, it Figure 2 showed that trend of coffee yield has declined. This implied, the increment in both quantity and value, was not because of increase in yield. Rather, it is because of increase in area allocation and output harvested. The highest and lowest value of export was 1,023,691,000 and 129,177,000 US\$, respectively. The former was recorded in 2014 while the latter was obtained in 1993.

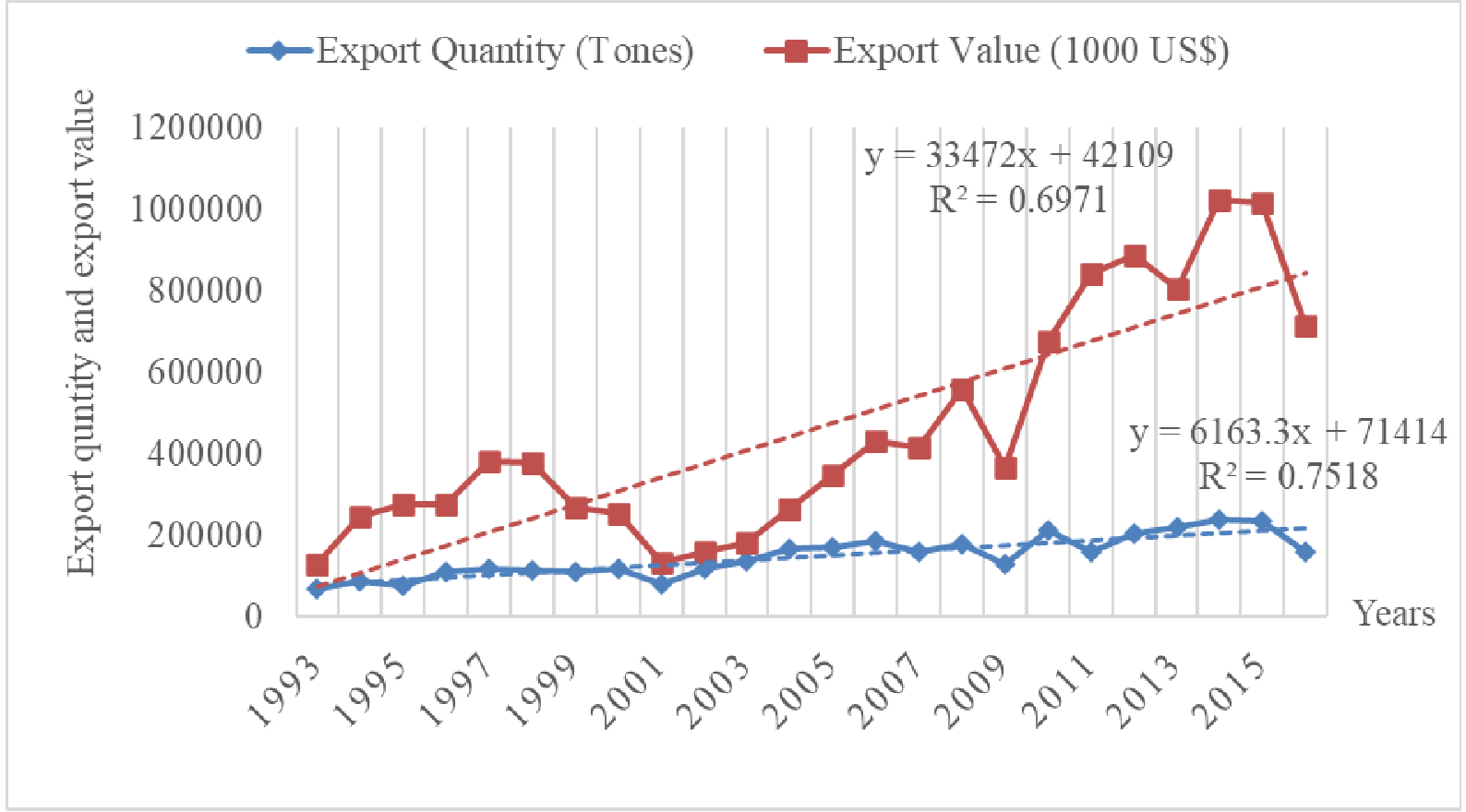

Figure 4: Trends of coffee export quantity and value

Source; Own computation from FAOSTAT data, 2019.

\subsubsection{Domestic consumption}

Ethiopian is not only a major producer and exporter of coffee, but the highest consumer as well in Africa. Share of consumption in total production in the immediate years following initiation of the reform were relatively lower, decreasing from as high as $65 \%$ in 1987 to $25 \%$ in 2003 . The relatively smaller share of domestic consumption in production in the early years of the reform could be attributed to increases in exports observed in the country during that period as a result of increases in the number of exporters following the liberalization of internal marketing. It however has taken on an increasing trend since the year 2004 (Boansi and Crentsil, 2013). Similarly, Francom (2018) reported that Coffee consumption in Ethiopia is growing, albeit slowly as the population expands. In 2015/16 total production was 6.4 million $60 \mathrm{~kg}$ bags, of which 3.7 million were consumed within Ethiopia (Moat et al., 2017). An interesting new development in Ethiopian major cities regarding coffee consumption is the emergence of small roadside stalls selling coffee to passer by customers. The small roadside stalls serve coffee in a traditional manner. They have emerged and flourished in Ethiopia's major towns, growing very popular among coffee consumers who are frustrated by the escalating price of coffee and the deteriorating quality of coffee served in cafes and coffee shops. Unlike regular coffee shops, the small roadside stalls pay neither VAT nor house rents making their cost of serving coffee much lower and more competitive than the regular coffee shops (Alemayehu, 2014).

Coffee in the local market is mainly coffee destined for export through the Ethiopian Commodity Exchange (ECX) but rejected for failing to meet ECX's quality standards. But, local coffee price is usually higher than international Coffee arabica prices (Alemayehu, 2014). According to Getachew (2011), mixing coffee with other grain crops such as barely is becoming a usual in the country.

Coffee plays a vital role in both cultural and social life of Ethiopian community. Among coffee producing countries in the world, Ethiopia is the first country in consumption of coffee. From the 200,000-250,000 tons of average annual production, about $50 \%$ is consumed in the country. Preparation and drinking of coffee is a unique culture in Ethiopia; coffee ceremony. Coffee is not drunk alone. It is a social activity to be shared with others. Sharing coffee with others means you are at peace with them and cultivates community and friendship (Melkamu, 2015).

\subsection{Empirical Review on Marketing Margin Analysis of coffee along its value chain in Ethiopia}

According to Getachew (2011) the total marketing margin for coffee marketing in the eastern Ethiopia was Birr 20 per a kilogram of dried cherries produced and sold by farmers. Among the actors in coffee marketing channel, 
retailers receive the highest marketing margin, which is more than $79 \%$ of the total marketing margin. They have also the highest margin as percent of the cost prices (average buying price and marketing costs), which is $31.75 \%$. For instance, retailers earn a profit of Birr 2891.76 from selling 1 quintal of hulled and prepared coffee, while wholesalers only obtain a profit of Birr 394.4, which is 7 fold smaller than the amount earned by retailers. Even farmers, who are engaged in coffee production the whole year, obtained only $45 \%$ of the margin grained by retailers. It can also been seen that $67 \%$ of the retail value (final price paid by consumer) goes to farmers, while the remaining $33 \%$ is taken by traders ( $7 \%$ by wholesalers and $26 \%$ by retailers).

Similarly, Zekarias et al. (2012) studied market chains of forest coffee in southwest Ethiopia and reported that the producers obtained less net benefit than other intermediaries. Net benefit analysis was used for the actors in the chain to examine/evaluate the performance of the market. Larger average net profit was obtained by the intermediaries than the producers and producers ware less beneficiaries in the chain than the other actors.

Table 2: Marketing Margin Analysis of coffee along value chain in eastern and south west Ethiopia

a) Marketing margin analysis of coffee in Eastern Ethiopia

\begin{tabular}{|c|c|c|c|c|c|}
\hline & & & & \multicolumn{2}{|c|}{ Profit margins } \\
\hline Cost items & $\begin{array}{c}\text { costs and price } \\
(\text { Birr } / \mathrm{kg})\end{array}$ & $\begin{array}{c}\text { Gross } \\
\text { marketing } \\
\text { margin }\end{array}$ & Total costs & Amount & $\begin{array}{c}\% \text { of total } \\
\text { cost }\end{array}$ \\
\hline Farmer & & 40 & 33.7 & 6.3 & 18.69 \\
\hline Costs of production & 33.2 & & & & \\
\hline Marketing cost & 0.5 & & & & \\
\hline Total cost & 33.7 & & & & \\
\hline Producer price & 40 & & & & \\
\hline Wholesaler & & 4.1176 & 2.1456 & 1.972 & 4.68 \\
\hline Average buying price & 40 & & & & \\
\hline Total marketing cost & 2.1456 & & & & \\
\hline Total cost & 42.1456 & & & & \\
\hline Selling price at ECX & 44.1176 & & & & \\
\hline Retailer & & 15.8824 & 1.4236 & 14.459 & 31.75 \\
\hline Buying price & 44.1176 & & & & \\
\hline Marketing costs & 1.4236 & & & & \\
\hline Total cost & 45.5412 & & & & \\
\hline Selling price & 60.00 & & & & \\
\hline
\end{tabular}

b) Average net profit of actors in one production season of coffee in south west Ethiopia

\begin{tabular}{lcccccc}
\hline Costs and sales in Birr & \multicolumn{2}{c}{ Producers } & Assemblers & \multicolumn{3}{l}{ Local wholesalers } \\
\cline { 2 - 7 } & Gera & Shebe & Gera & Shebe & Gera & Shebe \\
\hline Gross value of sale (birr) & 22,453 & 9,520 & 323,080 & 196,800 & $2,823,529$ & $1,710,000$ \\
Cost & & & & & & \\
Value of purchase & - & - & 170,000 & 89,250 & $1,700,000$ & 892,500 \\
Processing Cost & - & - & 3600 & 3000 & 60,000 & 58,500 \\
Packing cost & - & - & 4200 & 3900 & 42,000 & 36,000 \\
Loading cost & 520 & 160 & $11,666.67$ & 625 & 103,433 & 6,000 \\
Transportation cost & & & & & & 45,000 \\
Cost for commission & - & - & - & - & 24,498 & \\
men & 520 & 160 & $189,866.67$ & 97,075 & $1,938,231.50$ & $1,038,000$ \\
Total cost & $\mathbf{2 1 , 9 3 3}$ & $\mathbf{9 , 3 6 0}$ & $\mathbf{1 3 3 2 1 3 . 3 3}$ & $\mathbf{9 9 7 2 5}$ & $\mathbf{8 8 5 , 2 9 7}$ & $\mathbf{6 7 2 , 0 0 0}$ \\
Net profit &
\end{tabular}

Source; Getachew, 2011; Zekarias et al., 2012

\subsection{Marketing Constraints of Coffee in Ethiopia}

Despite positive image of the country as birthplace of coffee, a strong local coffee culture, genetic diversity and easy branding opportunities, diverse agro-ecology and climatic conditions, unique distinct characters of coffee quality, a favorable national agriculture ecosystem for coffee development, the country, however, so far failed to fully capitalize its potential. The effect of price volatility has been a direct factor in increasing rural poverty in rural communities; up to $85 \%$ of coffee farmers have cited coffee price volatility as a leading risk factor for their farms. Episodic pricing pressures on smallholders lead some to shift away from traditional forest coffee production systems towards more immediately profitable zero-shade systems that can yield higher returns in the short term. However, this is having a profound impact on the degradation of coffee landscapes on longer time 
scales and farmers' ability to maintain natural assets and stable socio-economic conditions (UNDP, 2012). Similarly, Berhanu (2017) and Alemayehu (2014) reported that coffee producers are exposed to large fluctuation in market price. Poor accesses to market, little market promotion and incentive mechanism, and low price shares and benefit (farmers) are also another coffee marketing problem in Ethiopia (Jose, 2012; Tesfu, 2012).

\section{Conclusion and Recommendation}

This review provides an overview on coffee production and marketing constraints, marketing actors and margin distribution in Ethiopia. According to the review, lack of competitiveness, lack of infrastructure, in adequate access to services, low value addition, in adequate technology transfer and research, competition of khat and rainfall variability are among major constraints of coffee production in Ethiopia. Price volatility, Poor accesses to market, little market promotion and incentive mechanism, and low price were reported to be the major problem of coffee marketing in Ethiopia. The review revealed that larger average net profit was obtained by the intermediaries than the producers and producers ware less beneficiaries in the coffee market chain than the other actors.

Depending on the review made, the following recommendation has been given.

$\checkmark$ The government should Increase producers (farmers) share of final retail price through enhancing of competition among traders in the market by licensing more traders and inspecting their activities.

$\checkmark$ Enhancing infrastructural and institutional facilities such as market information, road and transportation

$\checkmark$ Improving of coffee production technologies through development and extension of improved coffee varieties and other related agronomic practices.

\section{Reference}

Alemayehu Asfaw. 2014. Coffee production and marketing in Ethiopia. European Journal of Business and Management, 6(37).

Armstrong, G. and Kotler, P. 2015. Marketing: An Introduction, $12^{\text {th }}$ Edition. Pearson Education, USA.

Bastin, A. and Matteucci, N. 2007. Financing coffee farmers in Ethiopia: Challenges and Opportunitie, 31(3): 251-282.

Boansi, D. and Crentsil, Ch. 2013. Competitiveness and determinants of coffee exports, producer price and production for Ethiopia. Corvinus University of Budapest, Hungary, University of Reading, UK.

BerhanuTsegaye. 2017. Ethiopian Coffee Sector Strategy and Future Prospects. Coffee Tea and Spices Extension Director ECTDMA, Addis Ababa, Ethiopia.

CSA (Central Statistical Agency). 2012/13. Reports on area and production of crops (Private Peasant Holdings, Meher Season). Addis Ababa, Ethiopia.

CSA (Central Statistical Agency). 2013/14. Reports on area and production of crops (Private Peasant Holdings, Meher Season). Addis Ababa, Ethiopia.

CSA (Central Statistical Agency). 2014/15. Reports on area and production of crops (Private Peasant Holdings, Meher Season). Addis Ababa, Ethiopia.

CSA (Central Statistical Agency). 2015/16. Reports on area and production of crops (Private Peasant Holdings, Meher Season). Addis Ababa, Ethiopia.

CSA (Central Statistical Agency). 2016/17. Reports on area and production of crops (Private Peasant Holdings, Meher Season). Addis Ababa, Ethiopia.

CSA (Central Statistical Agency). 2017/18. Reports on area and production of crops (Private Peasant Holdings, Meher Season). Addis Ababa, Ethiopia.

Crawford, M. 1997. Agricultural and Food Marketing Management. Rome: Food and Agriculture Organization of the United Nations.

Edward Batte, Admit Wondifraw, James Wakiaga and Haile Kibret. 2017. African Development Bank, Organization for Economic Co-Operation and Development, United Nations Development Program.

FAO (Food and Agriculture Organization). 2014. Ethiopia country programming frame work, revised document. Addis Ababa, Ethiopia.

FAOSTAT. 2019. Accessed on February 2019 from www:fao.org/faostat//en/\#data/.

Francom, G. 2018. Ethiopia coffee annual report. GAIN report number ET1710, GAIN report assessment of commodity and trade by USDA, USA.

Gardner, L. and Rausser, G. 2001. Marketing, Distribution and Consumers: Hand Book of Agricultural Economics, Volume 1B. North Holland.

Getachew Dema. 2011. Coffee market performance analysis: A case of Eastern Ethiopia.

ILRI (International Livestock Research Institute). 2005. Improving Productivity and Market Success of Ethiopian Farmers.

Jose, D. 2012. Ethiopian coffee: Challenges and opportunities. Ethiopian coffee export conference, Addis Ababa, Ethiopia. 
Kotler, P., Armstrong, G., Saunders J. and Wong, V. 1999. Principles of Marketing, $2^{\text {nd }}$ European Edition. Prentice Hall, Inc, New Jersey, USA.

Labouisse, J., Bayetta, B., Surendra, K. and Bertrand, B. 2008. Current status of coffee (Coffea arabica L.) genetic resources in Ethiopia: implications for conservation. Genet Resour Crop Evol, 55:1079 -1093.

Melkamu Alemayehu. 2015. Ethiopian Highlands: Home for Arabica Coffee (Coffea arabica L.).

Moat, J., Williams, J., Baena, S., Wilkinson, T., Demissew, S., Challa, Z.K., Gole, T. W. and Davis, A.P. 2017. Coffee farming and climate change in Ethiopia: Impacts, forecasts, resilience and opportunities. The Strategic Climate Institutions Programme (SCIP). Royal Botanic Gardens, Kew (Uk). Pp. 37.

Mohammad, A. 2004. Agricultural market development in Ethiopia: Problems and Issues. International Livestock Research.

NBE (National Bank of Ethiopia). 2018. Domestic economic analysis and publications directorate. Quarterly bulletin first quarter 2017/18 Fiscal Year Series, Addis Ababa, Ethiopia.

Nicolas Petit. 2007. Ethiopia's Coffee Sector: A Bitter or Better Future. Journal of Agrarian Change, 7 (2):225263.

Palmatier, W., Stern, W. and El-Ansary, I. 2015. Marketing channel strategy, $8^{\text {th }}$ Edition. Pearson Education, Inc., Prentice Hall, One Lake Street, Upper Saddle River, New Jersey 07458.

Samuel Gebreselassie and Eva Ludi. 2008. Agricultural commercialization in coffee growing areas of Ethiopia.

Scarborough, V and Kydd, J. 1992. Economic Analysis of Agricultural Markets: A Manual. Chatham, U.K.: Natural Resources Institute.

Tadesse Woldemariam. 2003. Conservation and use of coffee genetic resources in Ethiopia: challenges and opportunities in the context current global situations.

Tadesse Woldemariam. 2015. Coffee production systems in Ethiopia: Ethiopia Environment and Coffee Forest Forum, Addis Abeba, Ethiopia.

Tesfaye Hailu. 2016. Challenges and Prospects of Agricultural Marketing in Konta Special District, Southern Ethiopia. Journal of Marketing and Consumer Research, Vol.28.

Tesfu Kebede. 2012. Coffee quality and productivity as basic factors for sustainability in Ethiopia. $21^{\text {st }}$ African Coffee Sustainability Forum, United Nations Conference Center at Addis Ababa (UNCC-AA), Addis Ababa, Ethiopia.

Tolera FG and Gebermedin GA. 2015. Opportunities and constraints of coffee production in West Hararghe, Ethiopia. Journal of Agricultural Economics and Rural Development, 2(4): 054-059.

Tomek, W. G. and Kaiser, H. M. 2014. Agricultural Product Prices, $5^{\text {th }}$ Edition. Cornell University Press, Ithaca and London.

(UNDP) United Nations Development Programme. 2012. Proposal for coffee platform in Ethiopia. Addis Ababa, Ethiopia.

Wolday Amha. 1994. Food grain marketing development in Ethiopia after reform 1990. A case study of Alba Seraro.The PhD Thesis, Verlag Costar University.

Zekarias Shumeta, Kaba Urgessa and Zerihun Kebebew. 12. Analysis of Market Chains of Forest Coffee in Southwest Ethiopia. Academic Journal of Plant Sciences, 5 (2): 28-39.

Zelalem Girma. 2016. Ethiopia re-established Coffee and Tea Authority to commence operation. 